\title{
The Roles of Islamic Religiosity, Brand Image and Knowledge on Relationship between Perceived Value and Tourist Satisfaction: A Review
}

\author{
Nashrul Hakimi ${ }^{1}$, Noorshella Che Nawi ${ }^{1}$, Mohamad Ismail ${ }^{1}$, Md Zaki Muhamad Hasan ${ }^{1}$, Asrul Hery Ibrahim ${ }^{1}$ \& \\ Noorul Azwin Md Nasir ${ }^{1}$ \\ ${ }^{1}$ Faculty of Entrepreneurship and Business, Universiti Malaysia Kelantan,Kota Bharu Kelantan, Malaysia \\ Correspondence: Noorshella Che Nawi, Faculty of Entrepreneurship and Business, Universiti Malaysia Kelantan, \\ Kota Bharu Kelantan, Malaysia. E-mail: norshella@umk.edu.my
}

Received: March 15, 2018

doi:10.5539/ijbm.v13n8p101
Accepted: June 25, 2018

Online Published: June 30, 2018

\begin{abstract}
Islamic tourism industry must be innovative to remain competitive in an increasingly global economic. This conceptual paper examines the relationship between key component and factor that can affect the customer satisfaction in the Islamic tourism industry. The paper conceptualizes perceived value, brand image and Islamic attributes to studies the relationship that exists in the industry. The paper also uses knowledge and religiosity to investigate the moderate factor that exists in the framework between Islamic attributes and customer satisfaction. This paper will shed some light on measuring customer behavior in tourism from Islamic perspective. The dimension use in this paper also could be used as a base for tailoring Islamic tourist packages.
\end{abstract}

Keywords: Islamic tourism, religiosity, customer satisfaction, brand image, Islamic attributes, perceived value

\section{Introduction}

Muslim market is one of the latest growing market segments in the world. Muslim countries, such as Malaysia, United Arab Emirates, Turkey and Indonesia have developed Islamic tourism in marketing the country as a holiday destination for Muslim travelers. Non-Muslim countries, such as Japan, Korea, Thailand and Europe also show great interest to attract this market. According to Crescentrating statistics, in 2014 Malaysia, Turkey and the UAE were among the top Muslim-friendly destinations for religious visitors. Another statistic defined the expenditure of the halal tourism sector as more than $\$ 145$ billion in 2014 (Crescentrating, 2015). With the increased purchasing power of Muslims tourists, the fastest growing trends in halal tourism attract many marketers (Battour, Battor, \& Ismail, 2012). The increasing number of products and services specifically catering to Islamic norms and sensitivities, which are being introduced worldwide, is considered to be a positive trend by many marketers. According to the Global Economic Report, 2014-2015, global Muslim population is expected to grow by about $35 \%$ over the next 20 years, rising from 1.6 billion in 2010 to 2.2 billion by 2030 , it is make known that Halal industry offers opportunities to Muslim countries worldwide. This is true when Muslim travelers spend with average $10 \%$ to $50 \%$ higher than that of the average leisure or business traveler (Hotelier Middle East, 2008d; Sahafa, 2008b; Rosenberg and Choufany, 2009; Samori and Rahman, 2013).

\subsection{Problem Statement}

According to Jaswir and Ramli (2016) many complaints regarding tourism service in Malaysia had been received such as misleading advertisement, low quality of services, fraud holiday package and inefficient services. Studies regarding the relationship in Islam and tourism still few especially in Muslim countries that label themselves as Islamic Hub (Shafaei, 2015). Battour et al. (2011) stated even tourism were explored widely, still there is few of study in the Islamic tourism and the impact on customer in Islamic tourism marketing. This supported by Eid and Gohary (2015) stated future research is needed to investigate the relationship between perceived values with additional others factor which will fulfill Muslim satisfaction. Customer satisfaction is an important key to measuring the expectation of customer toward the destination so the provider can improve the quality of service that can satisfy tourist need and want (Meng, Tepanon, Uysal, 2008). According to Meng et all (2008) in the studies of measuring tourist satisfaction by attributes and motivation on case of nature-based resort conducted in South-east Virginia, the tourist satisfaction can be measure by the attributes, performance and 
motivation.According to Battour, Ismail and Battor (2013) based on studies of Islamic attributes and the impact to Islamic tourism, the studies can help marketers to define and understand the Islamic Tourism so they can develop strategies that can persuade Muslim tourist to repurchase the service. The studies that conducted in Kuala Lumpur show highly significant result between the impacts of Islamic attributes toward customer satisfaction. One of the studies conducted by Eid and Gohary (2015) based on studies in Islamic tourism show significant result, the studies concluded that perceived value and Islamic attributes has significant relationship toward customer satisfactions moderate by the religiosity. The studies conducted in United Kingdom, Egypt and United Arab Emirates provided significant result to the findings of studies. Perceived value is the ultimate outcome of marketing activities (Prebensen, 2013) to measure customer post purchased behavior. According to Eid (2013) marketing scholars has long studied perceived value and proposed various conceptualizations of the perceived value. Still, the studies on perceived value in Islamic Tourism perspective are still few. Eid suggests, the studies in dimensions of perceived value toward Islamic Tourism must be undertaken to determine behavioral intention for Islamic tourism. This is because the rating of tourism products in the case of Islamic tourism participation is far different process because of necessity of Islamic Shari'ah.Studies taken in the area of Islamic attribution do not receive attention by the researchers even though the Muslim Population has emerged as a world market (Battour, Battor, \& Bhatti, 2013). The studies conducted by Eid (2013) recommend the future research is needed to investigate Islamic attributes of destination which will fulfill Muslim satisfaction. Islamic attributes requirement is significant to every Muslim, this principle is important because religious deeds are not acceptable as they are not conducted appropriately. The relationship between tourism and religion has been discussed in various previous tourism literatures (Battour, Ismail and Battor, 2011; Eid, 2013; Henderson, 2011; Jafari and Scott, 2014: Eid and Gohary, 2015). Alam, Mohd, and Hisham (2011) find that religious Muslims consider Islam to be their source of reference. They argue that religiosity plays a full moderating role in the relationship between contextual variables and the purchasing behavior of Muslim consumers. However, although previous research has examined the relationship between perceived customer value and consumer satisfaction, there has been only limited investigation into the impact of religiosity on the relationship between customer value and customer satisfaction (Eid and Gohary, 2015).Knowledge on the Islamic industry has be widely discussed on the previous literature (Azmawani and Suhaimi, 2015: Junainah, 2016; Yasuda, 2017) but there are lack of research that include knowledge to determine relationship between perceived value, Islamic attributes and customer satisfaction in Islamic tourism industry. Therefore, this study will investigate the relationship between perceived value and Islamic attributes toward customer satisfaction and include religiosity and knowledge as moderate to Islamic attributes and customer satisfaction.

\section{Literature Reviews}

\subsection{Customer Satisfaction}

The customer satisfaction is important for tourism industry to receive more market expose in local and foreign market. Customer satisfaction is crucial in order to make sure the market successful (Battour, 2014). Satisfaction can be received with the emotional response that trigger by a cognitive response such as quality of services and past experienced. It also can be influence by cognitive side of service activities such as destination image, perceived value and consumer's expectation (Rahman, 2014). According to Rodriguez del Bosque and Martin (2008), customer satisfaction does not only response by cognitive but also emotional. All literature from past studies contains significant differences in the definition of satisfaction. But Eid (2013) in his studies in perceived value conducted in United Kingdom, Egypt and the United Arab Emirates stated that there are least two formulation of satisfaction, one is transient (transaction-specific) and the others is overall satisfaction (Cumulative).Transient satisfaction is based on evaluation of activities and behavior that take place during the single or discrete interaction at the service encounter (Oliver, 1997). The past studies from Nam, Ekinci, and Whyatt (2011) suggested, transient satisfaction can be seized right away after each service interaction with the service provider. In other hand, overall satisfaction is the evaluation judgment of the last purchase and based on all encounters with the service provider (Ekinci, Dawes, and Massey, 2008; Nam et al, 2011) Transient satisfaction is the result from experience to experience, whereas overall satisfaction is a moving average that can show stable and most similar result to an overall attitude of purchasing. This study will follow transient satisfaction from Oliver (1977) and view consumer satisfaction as the overall emotional response to the service experience on the single transaction as the post purchasing point.

\subsection{Perceived Value}

The term perceived reflect the existential view, in which value judgment is dependent on the customer's experience. Studies from Heeler, Nguyen and Buff, (2007) treated the perceived value as the dependent measure rather than a driver with behavior. But others study from Prebensen (2013); Eid and Gohary (2015) view 
perceived value as independent variable. In previous years, perceived value has been the object of interest for many researchers and marketing scholar in hospitality and tourism industry. Perceived value is a subjective and dynamic construct that show the degree of different tourist and cultures at different times, and it is necessary to include emotional or subjective reaction that are generated in consumer's mind Prebensen (2013); Sweeney and Soutar (2001). In addition, some studies on perceived value by Ravald and Gronross (1996) found out that perceived value affected trust and customer satisfaction. Studies of perceived value conducted in Australian by Chen and $\mathrm{Hu}$ (2010) stated the functional value is therefore defined as an overall assessment of value incorporating quality, the traditional value for money, and convenience characteristics. This type of value represents the customer's perception of quality in terms of goods and services received, the price paid for those goods and service, and the time saving to receive them. Cognitive value is defined as an overall representation of experiential value perceptions from the social, emotional, the aesthetic, and reputation aspects. This value represents the customers' impression on others, perception of delight or pleasure, enjoyment of the visual appeal, and reputation of outlet, involved with the consumption experience. The study suggested examining wider dimension of perceived value and not focusing only on functional value. Another studies from Lee, Lee, and Choi, (2011) conducted in 12th Boryeong Mud Festival, Seoul, South Korea stated that important of emotional value in addition to functional value. The study suggested to examine the others potential factor that might influence the perceived value. In addition, studies conducted by Eid and Gohary (2013) in United Kingdom, Egypt and the United Arab Emirates show perceived value dimension quality, price, emotional and social provide significant result to the study. The paper recommends furthering the research on the dimension for benefit of theoretical and practical purpose. Another studies by Oktora and Achyar (2014) conducted in Jakarta, Indonesia in post-purchase perceived value suggested more studies must be conducted in perceived value dimension especially in price to determine the effect toward Islamic tourism.

\subsection{Islamic Attributes}

Religious identity appears to play an important role in shaping the experience to customers. This is because some religious teach their followers codes of behavior that may encourage or discourage them from being customers to the tourist industry. For example, people, because of their religious beliefs, find public alcohol consumption to be very offensive (Battour, Ismail and Battor, 2011; Jafari and Scott, 2013). Islamic attribution is important to Muslim because of the way Islam teaching to avoid adultery, gambling, consumption of pork and others haram food such as alcohol. Studies conducted by Bogari, Crowther and Marr (2004) in Saudi Arabia claim that destination attributes and issues related to Islamic culture have not been sufficiently explored by researchers. Thus, researcher must focusing more on discovers the area in Islamic attributes. Another studies about motivating factors of Islamic tourist's destination loyalty conducted by Rahman (2014) in Kuala Lumpur stated the good and proper Islamic attributes can motivate Muslim travel. The author stated that Islamic tourism is important issues, the paper state there a need more for a comprehensive research on Islamic attributes. Research on Muslim Tourism has not received a good attention even though Muslim population has become the global market (Battour, Battor, Bhatti, 2014). Another studies in Islamic tourism conducted by Eid (2015) in the United Kingdom, Egypt and United Arab Emirates stated the Muslim tourist evaluate the satisfaction not only founded on traditional aspects of value (perceived value that include dimension of quality, price, emotional and social) but also religious characteristic that contribute to the creation of value. The perceived value and Islamic attributes is the overall version underlies the multidimensional approach to consumer's perceived value. The studies also recommended concentrating more on Islamic attributes to generate depth knowledge of theoretical and practical application. Studies in Islamic attributes of destination by (Battour, Battor and Bhatti, 2014) in Kuala Lumpur stated Islamic attributes have a positive impact on overall tourist satisfaction, which is linked to destination choice. Therefore, it was recommended to investigate the relationship between Islamic attributes of destination and overall tourist satisfaction. The studies also recommend future research to focus more on Islamic attributes to increase the understanding about the field of attributes.

\subsection{Brand Image}

Roberts and Dowling (2002) stated brand can be helpful to gain a good performance. Brand image also can be seeing as intangible asset which mean it difficult to imitate. According to Kotler and Armstrong (2010) brand image show the overall perception based on past customers' experience with the brand. Brand image also can be seeing as what comes into the consumers mind when brand placed in front of him (Saleem and Raja, 2014). Qomariah (2017) stated the image of the brand relates to an attitude of belief and preference for a brand and consumers who have a positive image of a brand will be more likely to make a purchase. Travel agency brand image generate a strategic function. Through strategic marketing activities, travel agency brand image can be used to help it improve the competitive position in the industry (Javalgi, Thomas and Rao, 1992). Thus, a 
favorable travel agency brand image helps strengthen the intentions customers have for selecting a travel agency. The positive image can attract customers to repurchase the product and services that provided. The research on brand image and customer satisfaction and loyalty conducted by Suwandi, Andi Sularso, and Imam Suroso (2015) stated that brand image impacts customer satisfaction but does not affect customer loyalty. Another studies conducted by Qomariah (2012) stated that good institution image not only can increase student's satisfaction, but institution image also can increase customer loyalty. Studies on hospital image by Wu (2011) conclude that brand image is the main antecedent in the studies. The brand image not only increase loyalty but it also enhances satisfaction with the improvement of perceived service quality and promote revisit intention of the patients.

\subsection{Knowledge}

Generally, knowledge refers to the facts, feelings or experiences known by a person or a group of people; it can also be defined as awareness, consciousness or familiarity gained by experience or learning (Rahman, Asrarhaghighi, \& Rahman, 2015). According to Ahmad et al (2015) if consumers have additional knowledge about the product, it will positively influence the consumer attitude toward the product. After consumers acquire and recall different information, the decision making can variety based of different pattern information based (Mahiah, Faridah, Rosidah and Rahman, 2013). Daud (1989) stated in Islam, Muslims who have knowledge will be positive fear to God and follow the principles of Islamic religious life. To be specific, knowledge means the expertise and skills acquired by a person or a group of people through theoretical or practical understanding of a subject (Radzi, Zahari, Muhammad, Aziz and Ahmad, 2011; Maimone and Sinclair, 2010). From consumer awareness view, Muslim customers in a multi religious country are more sensitive and aware about halal and haram than a country that have majority of Muslims (Junaidah and Razali, 2016). Junaidah and Razali (2016) stated increasing in knowledge also change the consumption of Muslim population and remain for their religious requirements. Past studies about the knowledge showed positive effect on consumer behavior. According Aertsens, Mondelaers, Verbeke, Buysse, and Huylenbroeck (2011), past researchers reported the additional awareness and knowledge about concerning organic food indicate positive influence on consumer's behavior towards consumption level of the product.

\subsection{Religiosity}

Religion is an under-researched topic in tourism marketing (Cleveland, Laroche, and Hallab, 2013). Religiosity defines the ideas about the way to live which are reflected in the values and attitudes of societies and individuals (Fam, Waller, and Erdogan, 2004). According to Sungkar (2010) religiosity also defined as individual committed to the religion and teachings. Religious commitment can affect the orientation of consumers regarding consumption patterns and social behavior (Mahiah et al., 2013). Religion considered as important indicator in decision making processes that can leads people to behave ethically and lawfully (Ahmad et al., 2015). Such values and attitudes shape the behavior and practices of institutions and people. Religiosity has long been known as a factor that influences human behavior, but in a secular society its influence on consumer behavior appears to be underestimated (Eid and Gohary, 2015). Elaziz, \& Kurt (2017) also stated that religion also influences customer decision making when purchase the product or services. Previous studies have indicated that religiosity can be a significant factor in regard to consumption patterns (Cleveland et al., 2013; Weaver and Agle, 2002), innovativeness (Mansori, 2012), advertising (Fam et al., 2004; Michell \& Al-Mossawi, 1995), family decision-making (Sim and Bujang, 2012), purchase risk aversion (Delener, 1990) and selected store patronage behavior (Alam et al., 2011; Battour et al., 2011; Mokhlis, 2009). However, past studies has focused on food and cosmetic products only. As such, this studies intent to bridge the focus into tourism studies for religiosity.

\section{Conclusion}

The main purpose of this study was to investigate the role of knowledge and religiosity on the relationship between the perceived value, Islamic attributes and brand image toward customer satisfaction in Islamic tourism. The study pointed 5 objectives to provide outcome for the analysis of the conceptual model. Contextual and theoretical contribution in the study is to explore the factor that influence the customer satisfaction from post purchased of Islamic tourism. Result from the study also can be use to reconstruct the Islamic travel package in the market right now. Business opportunity in Islamic tourism forecasted to grow in the coming years, individual and organizations involved in the industry must be more aware of the implications and greater opportunity in this industry.

\section{Acknowledgments}

This study was funded by the RMIC, Universiti Malaysia Kelantan, Malaysia; under the grant titled 'Short Term Research Grant (SGJP)'. Project title: The roles of Islamic religiosity, brand image and knowledge on the relationship between perceived value and tourist satisfaction in Malaysia. Total Grant: RM5,000.00 (Ringgit 
Malaysia).

\section{References}

Abd Rahman, A., Asrarhaghighi, E., \& Ab Rahman, S. (2015). Consumers and Halal cosmetic products: knowledge, religiosity, attitude and intention. Journal of Islamic Marketing, 6(1), 148-163. https://doi.org/10.1108/JIMA-09-2013-0068

Aertsens, J., Mondelaers, K., Verbeke, W., Buysse, J., \& Van Huylenbroeck, G. (2011). The influence of subjective and objective knowledge on attitude, motivations and consumption of organic food. British Food Journal, 113(11), 1353-1378. https://doi.org/10.1108/00070701111179988

Ahmad, A. N., Rahman, A. A., \& Ab Rahman, S. (2015). Assessing knowledge and religiosity on consumer behavior towards halal food and cosmetic products. International Journal of Social Science and Humanity, 5(1), 10. https://doi.org/10.7763/IJSSH.2015.V5.413

Battour, M., Battor, M., \& Bhatti, M. A. (2014). Islamic attributes of destination: Construct development and measurement validation, and their impact on tourist satisfaction. International Journal of Tourism Research, 16(6), 556-564. https://doi.org/10.1002/jtr.1947

Battour, M., Ismail, M. N., \& Battor, M. (2011). The impact of destination attributes on Muslim tourist's choice.International Journal of tourism research, 13(6), 527-540. https://doi.org/10.1002/jtr.824

Bogari, N. B., Crowther, G., \& Marr, N. (2004). Motivation for domestic tourism: A case study of the Kingdom of Saudi Arabia. Consumer Psychology of Tourism, Hospitality and Leisure, 3, 51-63. https://doi.org/10.3727/108354203774076625

Card, M. (2015). Crescent Rating. Global Muslim Travel Index.

Che, A., Mohd, R., Zahari, M., Abdul, A., \& Ahmad. (2011). The effect of factors influencing the perception of price fairness towards customer response behaviors. Journal of Global Management, 2(1), 22

Chen, P. T., \& Hu, H. H. (2010). The effect of relational benefits on perceived value in relation to customer loyalty: An empirical study in the Australian coffee outlets industry. International Journal of Hospitality Management, 29(3), 405-412. https://doi.org/10.1016/j.ijhm.2009.09.006

Cleveland, M., Laroche, M., \& Hallab, R. (2013). Globalization, culture, religion, and values: Comparing consumption patterns of Lebanese Muslims and Christians. Journal of Business Research, 66(8), 958-967. https://doi.org/10.1016/j.jbusres.2011.12.018

Daud, M. N. W. (1989). The concept of knowledge in Islam and its implications for education in a developing country.

Del Bosque, I. R., \& San Martín, H. (2008). Tourist satisfaction a cognitive-affective model. Annals of tourism research, 35(2), 551-573. https://doi.org/10.1016/j.annals.2008.02.006

Delener, N. (1990). The effects of religious factors on perceived risk in durable goods purchase decisions. Journal of Consumer Marketing, 7(3), 27-38. https://doi.org/10.1108/EUM0000000002580

East, H. M. (2008). Landmark hotel group launches Shariah brand across UAE and KSA. Retrieved October, 13, 2012.

Eid, R., \& El-Gohary, H. (2015). The role of Islamic religiosity on the relationship between perceived value and tourist satisfaction. Tourism Management, 46, 477-488. https://doi.org/10.1016/j.tourman.2014.08.003

Ekinci, Y., Dawes, P. L., \& Massey, G. R. (2008). An extended model of the antecedents and consequences of consumer satisfaction for hospitality services. European Journal of Marketing, 42(1/2), 35-68. https://doi.org/10.1108/03090560810840907

Elaziz, M. F., \& Kurt, A. (2017). Religiosity, consumerism and halal tourism: A study of seaside tourism organizations in Turkey. Turizam: međunarodni znanstveno-stručni časopis, 65(1), 115-128. https://hrcak.srce.hr/178635

Heeler, R. M., Nguyen, A., \& Buff, C. (2007). Bundles= discount? Revisiting complex theories of bundle effects. Journal of Product \& Brand Management, 16(7), 492-500. https://doi.org/10.1108/10610420710834940

Jaswir, I., \& Ramli, N. (2016). Study on Muslim-Friendly Hospitality in Malaysia. In Contemporary Issues and Development in the Global Halal Industry (pp. 59-66). https://doi.org/10.1007/978-981-10-1452-9_6

Javalgi, R. G., Thomas, E. G., \& Rao, S. R. (1992). US Pleasure Travellers' Perceptions of Selected European 
Destinations. European Journal of Marketing, 26(7), 45-64. https://doi.org/10.1108/03090569210016594

Kotler, P., \& Armstrong, G. (2010). Principles of marketing. Pearson education.

Lee, J. S., Lee, C. K., \& Choi, Y. (2011). Examining the role of emotional and functional values in festival evaluation. Journal of Travel Research, 50(6), 685-696. https://doi.org/10.1177/0047287510385465

Mahiah, S., Faridah, H., Rosidah, M., \& Rahman, N. (2014). Assessing Consumers. Perception, Knowledge and Religiosity on Malaysia's Halal Food Products"-Procedia-Social and Behavioral Sciences, 130, 120-128. https://doi.org/10.1016/j.sbspro.2014.04.015

Maimone, F., \& Sinclair, M. (2010). Chapter 12 Affective climate, organizational creativity, and knowledge creation: case study of an automotive company. In Emotions and Organizational Dynamism (pp. 309-332). Emerald Group Publishing Limited.

Mansori, S. (2012). Impact of religion affiliation and religiosity on consumer innovativeness; the evidence of Malaysia. World Applied Sciences Journal, 7(3), 301-307.

Meng, F., Tepanon, Y., \& Uysal, M. (2008). Measuring tourist satisfaction by attribute and motivation: The case of a nature-based resort. Journal of vacation marketing, 14(1), 41-56. https://doi.org/10.1177/1356766707084218

Michell, P. C., \& Al-Mossawi, M. (1995). The mediating effect of religiosity on advertising effectiveness. Journal of Marketing Communications, 1(3), 151-162. https://doi.org/10.1080/13527269500000015

Mokhlis, S. (2009). Relevancy and measurement of religiosity in consumer behavior research. International Business Research, 2(3), 75. http://dx.doi.org/10.5539/ibr.v2n3p75

Nam, J., Ekinci, Y., \& Whyatt, G. (2011). Brand equity, brand loyalty and consumer satisfaction. Annals of Tourism Research, 38(3), 1009-1030. https://doi.org/10.1016/j.annals.2011.01.015

Oktora, K., \& Achyar, A. (2014). The Effect of Post-Purchased Perceived-Value Towards The Relationship Quality Of Hajj And Umrah Travel Agencies In Indonesia. The South East Asian Journal of Management, 8(1), 29. https://doi/org/10.21002/seam.v8i1.3100

Oliver, R. L., Rust, R. T., \& Varki, S. (1997). Customer delight: foundations, findings, and managerial insight. Journal of retailing, 73(3), 311-336. https://doi.org/10.1016/S0022-4359(97)90021-X

Prebensen, N. K., Woo, E., Chen, J. S., \& Uysal, M. (2013). Motivation and involvement as antecedents of the perceived value of the destination experience. Journal of Travel Research, 52(2), 253-264. https://doi.org/10.1177/0047287512461181

Qomariah, N. (2012). Pengaruh Kualitas Layanan dan Citra Institusi terhadap Kepuasan dan Loyalitas Pelanggan (Studi pada Universitas Muhammadiyah di Jawa Timur). Jurnal Aplikasi Manajemen, 10(1), 177-187.

Qomariah, N. (2017). Impact of Customer Value, Brand Image and Product Attributes to Satisfaction and Loyalty Tourism Visitors in Jember Regency. Mediterranean Journal of Social Sciences, 8(5S1), 129.

Radzi, S. M., Mohd Zaharí, M. S., Muhammad, R., Aziz, A. A., \& Ahmad, N. A. (2011). The effect of factors influencing the perception of price fairness towards customer response behaviors. Journal of Global management, 2(1), 22-38.

Rahman, M. K. (2014). Motivating factors of Islamic tourist's destination loyalty: an empirical investigation in Malaysia. Journal of Tourism and Hospitality Management, 2(1), 63-77.

Ravald, A., \& Grönroos, C. (1996). The value concept and relationship marketing. European journal of marketing, 30(2), 19-30, https://doi.org/10.1108/03090569610106626

Roberts, P. W., \& Dowling, G. R. (2002). Corporate reputation and sustained superior financial performance. Strategic management journal, 23(12), 1077-1093, https://doi.org/10.1002/smj.274

Rosenberg, P., \& Choufany, H. M. (2009). Spiritual Lodging - the Sharia - Compliant Hotel Concept. HVS Global Hospitality Services- Dubai, (April), 1-7. https://doi.org/10.1016/j.dss.2003.08.004

Saleem, H., \& Raja, N. S. (2014). The impact of service quality on customer satisfaction, customer loyalty and brand image: Evidence from hotel industry of Pakistan. Middle-East Journal of Scientific Research, 19(5), 706-711. https://doi.org/10.5829/idosi.mejsr.2014.19.5.21018

Samori, Z., \& Rahman, F. A. (2013). Towards the formation of Shariah complaint hotel in Malaysia: An exploratory study on its opportunities and challenges. Paper presented at the WEI International Academic 
Conference Proceedings, Istanbul, Turkey. https://doi.org/10.5829/idosi.mejsr.2014.19.5.21018

Shafaei, F., \& Mohamed, B. (2015). Involvement and brand equity: a conceptual model for Muslim tourists. International Journal of Culture, Tourism and Hospitality Research, 9(1), 54-67. https://doi.org/10.1108/IJCTHR-06-2014-0050

Shah Alam, S., Mohd, R., \& Hisham, B. (2011). Is religiosity an important determinant on Muslim consumer behaviour in Malaysia? Journal of Islamic Marketing, 2(1), 83-96. https://doi.org/10.1108/17590831111115268

Shyan Fam, K., Waller, D. S., \& Zafer Erdogan, B. (2004). The influence of religion on attitudes towards the advertising of controversial products. European Journal of Marketing, 38(5/6), 537-555. https://doi.org/10.1108/03090560410529204

Sim, A. K., \& Bujang, S. (2012). Work-family interface of hospitality industry in Malaysia: the moderating effects of religiosity. Asian Social Science, 8(8), 139. http://dx.doi.org/10.5539/ass.v8n8p139

Suhaimi, A. A. R. E. A. Ab Rahman.(2015). Consumers and halal cosmetic products: Knowledge, religiosity, attitude and intention. Journal of Islamic Marketing, 6(1). https://doi.org/10.1108/JIMA-09-2013-0068

Sungkar, I. (2010). Consumer awareness: thoughts and trends across the globe. The Halal Journal, 2(1), 22-28.

Suwandi, A. S., Dan, I. S. (2015). Pengaruh Kualitas Layanan, Harga Dan Citra Merek Terhadap Kepuasan Dan Loyalitas Pelanggan Pos Ekspres Di Kantor Pos Bondowoso Dan Situbondo.

Sweeney, J. C., \& Soutar, G. N. (2001). Consumer perceived value: The development of a multiple item scale. Journal of retailing, 77(2), 203-220. https://doi.org/10.1016/S0022-4359(01)00041-0

Weaver, G. R., \& Agle, B. R. (2002). Religiosity and ethical behavior in organizations: A symbolic interactionist perspective. Academy of management review, 27(1), 77-97.

\section{Copyrights}

Copyright for this article is retained by the author(s), with first publication rights granted to the journal.

This is an open-access article distributed under the terms and conditions of the Creative Commons Attribution license (http://creativecommons.org/licenses/by/4.0/). 